\title{
Large-sized theropod Spinosaurus: an important component of the carnivorous dinosaur fauna in southern continents during the Cretaceous
}

\author{
Carlos Roberto A. Candeiro ${ }^{1, *}$, Lívia Motta Gil ${ }^{1}$ and Pedro Ernesto Pontes de Castro ${ }^{1,2}$ \\ ${ }^{1}$ Universidade Federal de Goiás, Laboratório de Paleontologia e Evolução, Curso de Geologia, Campus Aparecida de Goiânia, \\ Rua Mucuri s/n Área 03 - St. Conde dos Arcos, 74968-755, Aparecida de Goiânia, GO, Brazil \\ 2 Pontifícia Universidade Católica de Goiás, Escola de cièncias Agrárias e Biológicas, Departamento de Biologia, \\ Avenida Engler 508 Bloco S - St. Jardim Mariliza, 74885-460, Goiânia, GO, Brazil
}

Received: 20 May 2017 / Accepted: 18 June 2018

\begin{abstract}
The Early Cretaceous of North Africa has Spinosaurinae dinosaur remains such as Spinosaurus recorded in Algeria (Guir Basin, Kem Kem beds), Egypt (Bahariya Formation), Morocco (Kem Kem beds), and Tunisia (Ain El Guettar Formation). Until now, three possible Spinosaurus species were identified: Spinosaurus aegyptiacus, Spinosaurus sp. and Spinosaurus "B". The occurrence of this genus in the AlbianCenomanian rocks of Africa suggests that the temporal and geographic distribution of these spinosaurines is the largest one among all genera and species of megapredators from the middle Cretaceous of Africa. The fossil record of Spinosaurus from the Albian to the Cenomanian shows a 20 million year persistence of this genus in Gondwanan ecosystems.
\end{abstract}

Keywords: theropod dinosaur / distribution / Early Cretaceous / Africa

Résumé - Spinosaurus (théropode de grande taille): une composante importante de la faune de dinosaures carnivores des continents méridionaux au cours du Crétacé. Le Crétacé inférieur d'Afrique du Nord renferme des restes de dinosaures spinosaurinés, tels que Spinosaurus répertorié en Algérie (Bassin du Guir, Kem Kem beds), en Égypte (Formation Bahariya), au Maroc (Kem Kem beds) et en Tunisie (Formation Ain El Guettar). Jusqu'à ce jour, trois espèces de spinosaure sont reconnues: Spinosaurus aegyptiacus, Spinosaurus sp. et Spinosaurus "B". La présence de ce genre dans les terrains albocénomaniens d'Afrique suggère que la répartition temporelle et géographique de ces spinosaurinés est la plus étendue de tous les genres et espèces de méga-prédateurs du Crétacé moyen d'Afrique. Le registre fossile de Spinosaurus, depuis l'Albien jusqu'au Cénomanien, indique une présence de 20 millions d'années pour ce genre dans les écosystèmes gondwaniens.

Mots clés : théropode dinosaure / distribution / Crétacé inférieur / Afrique

\section{Introduction}

Spinosaurus (Stromer, 1915) is the better known spinosaurid genus from the mid-Cretaceous of northern Gondwana. Its fossil remains have been reported to several localities in North Africa. In the literature, the paleogeographic distribution of this taxon is usually described to the Albian-Cenomanian of Algeria, Egypt, Morocco, and Tunisia (Bouaziz et al., 1988; Buffetaut, 1989; Russell, 1996; Taquet and Russell, 1998;

*Corresponding author: candeiro@ufg.br
Buffetaut and Ouaja, 2002; Dal Sasso et al., 2005; Bertin, 2010; Benyoucef et al., 2015).

Since Stromer's (1915) first publication on Spinosaurus aegyptiacus, many anatomical, taxonomic, phylogenetic, biogeographic and paleobiological papers about this genus have been published (e.g., Milner, 2003; Buffetaut et al., 2004; Dal Sasso et al., 2005; Rayfield et al., 2007; Benyoucef et al., 2015; Hendrickx et al., 2016). Nevertheless, there are few studies that detail the fossil record distribution of Spinosaurus. The aim of the present paper is to document and analyze the distribution of the Spinosaurus genus in northern Gondwana and to elucidate the coastal habitats occupied by the group during the mid-Cretaceous. 


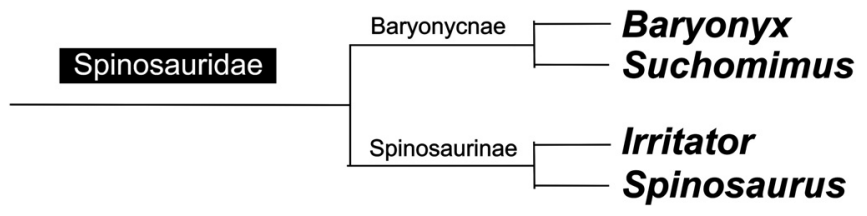

Fig. 1. Phylogenetic relationships of the middle Cretaceous species of the Spinosauridae family (modified from Hendrickx et al., 2016).

\section{Taxon rank}

Spinosaurus gives name to the family which includes two subfamilies: Baryonychinae and Spinosaurinae (Fig. 1). Baryonychinae includes the genus Baryonyx (Charig and Milner, 1986), reported from England, Spain, Portugal (Buffetaut, 2007; Bertin, 2010), and possibly Morocco (Buffetaut, 1989). This genus is closely related to Suchomimus (Sereno et al., 1998) which is recorded in Niger. The subfamily Spinosaurinae comprises the genera Spinosaurus (Martill and Hutt, 1996), from North Africa, and Irritator from northern Brazil (Hendrickx et al., 2016). The synapomorphies of Spinosaurinae include: non-curved tooth crown, absence of serrations in the tooth crown, alveoli relatively spaced apart, the first premaxillary tooth is much smaller than the second and third premaxillary teeth, large diastema within the premaxillary rosette (Sereno et al., 1998), a smooth lateral surface of the dorsal quadratojugal contact, presence of anterior and posterior margins delimiting the dorsal quadratojugal contact, quadrate foramen ventrally positioned (Hendrickx et al., 2016).

Hone and Holtz (2017) recently presented a summary of the synapomorphies of Spinosauridae. These synapomorphies are well-defined by: the presence of a premaxillary rosette; external nares positioned posteriorly to the premaxillary tooth row (Sereno et al., 1998); highly elongated maxillae; tooth crowns with subcircular cross-sections; a large elongation of the dorsal neural spines, being more than twice as high as the vertebral centra (Benson, 2010); presence of vertical grooves in tooth crowns; anterior carina placed at the base of the crown of maxillary teeth and dentary bones; presence of a ventral keel in the anterior and posterior dorsal and cervical vertebrae; and presence of pneumatic cavities at the center of the base of the neural spines, tilting towards the posterior dorsal region of the vertebra (Evers et al., 2015).

\section{Paleogeography and tectonic events of the mid-Cretaceous: a brief review}

During most part of the Mesozoic, the continental masses were divided into two main continents: Laurasia, in the Northern Hemisphere, and Gondwana, in the Southern Hemisphere (Pitman et al., 1993; Hay et al., 1999). By the end of the Cretaceous, these land masses had started to breakup, leading to the modern continental arrangement (Hay et al., 1999).

The split of Gondwana started in the Early Jurassic as a consequence of the rifting along the continental borders of what is today South America and Africa (including the northern border close to Europe). The rift continued during the Cretaceous when the South Atlantic ocean began to form, splitting Gondwana into eastern and western land masses
(Pitman et al., 1993; Arai, 2015; Melo et al., 2016; Strozyk et al., 2017; Charton et al., 2018). Eastern Gondwana comprised of Africa and India-Madagascar, while western Gondwana was made up of South America, Antarctica, and Oceania. By the end of the Cretaceous, India separated from Madagascar and moved northwest until its eventual collision with Eurasia. The land masses of eastern Gondwana - represented today by Africa - remained connected to South America and, during some periods, Europe until Albian (Hay et al., 1999; Canudo et al., 2009).

Two main paleogeographic features allowed spinosaurids to inhabit northern Gondwana and part of Laurasia (North Africa + northern Brazil + western Europe) during the middle Cretaceous: the "Western Gondwana bridge", present during the period where Africa was still connected to South America (Arai, 2015; Melo et al., 2016; Strozyk et al., 2017), and the sporadic pre-Cenomanian connection between Africa and Europe via the Iberian and Italian peninsulas (Canudo et al., 2009). Thus, these (possibly transitional) geographic connections between the north of the African plate and other land masses present at the end of the Early Cretaceous enabled faunal interchanges that affected directly the faunal composition of the terrestrial ecosystems of what today is Africa and influenced the evolution of the genus Spinosaurus.

Lastly, Africa was once an isolated area, separated from the Gondwana and Laurasia land masses, especially during the Cenomanian, but with some possible connection with southern Laurasia via Apulia and Iberian microplates (Pletsch et al., 2001; Zarconea et al., 2010; Torices et al., 2012). As a result, this continent did not share the same evolutionary history of its terrestrial animals with other areas of Gondwana and even Laurasia. Furthermore, Africa was affected by marine transgressions during the middle Cretaceous, that separated the African, European, and American marginal basins (e.g., São Luís, Tataouine, Humar, Shushan) (Candeiro, 2015; Candeiro et al., 2011, 2017). This isolation probably leads to a faunal differentiation from other areas.

\section{Spinosaurus records}

In the following, we present a brief description of the known records, localities, materials, and comments of Spinosaurus specimens from the Albian-Cenomanian of North Africa (Fig. 2, Tab. 1).

Albian-Tunisia

Spinosaurus cf. aegyptiacus Stromer, 1915

Geological unity and age: Chenini Member (Ain El Guettar formation), late Albian, Tunisia.

Material: BM231 - rostral part of the left dentary with two teeth.

Comments: Buffetaut and Ouaja (2002) described an incomplete dentary from the Chenini member (late Albian) in the region of Jebel Miteurda, province of Tataouine, Southern Tunisia. According to the authors, this material is similar to the species' holotype, yet it is smaller than the Spinosaurus aegyptiacus described by Stromer (1915).

\section{Cenomanian-Egypt}

Spinosaurus aegyptiacus

Geological unity and age: Bahariya formation, Cenomanian, Egypt. 


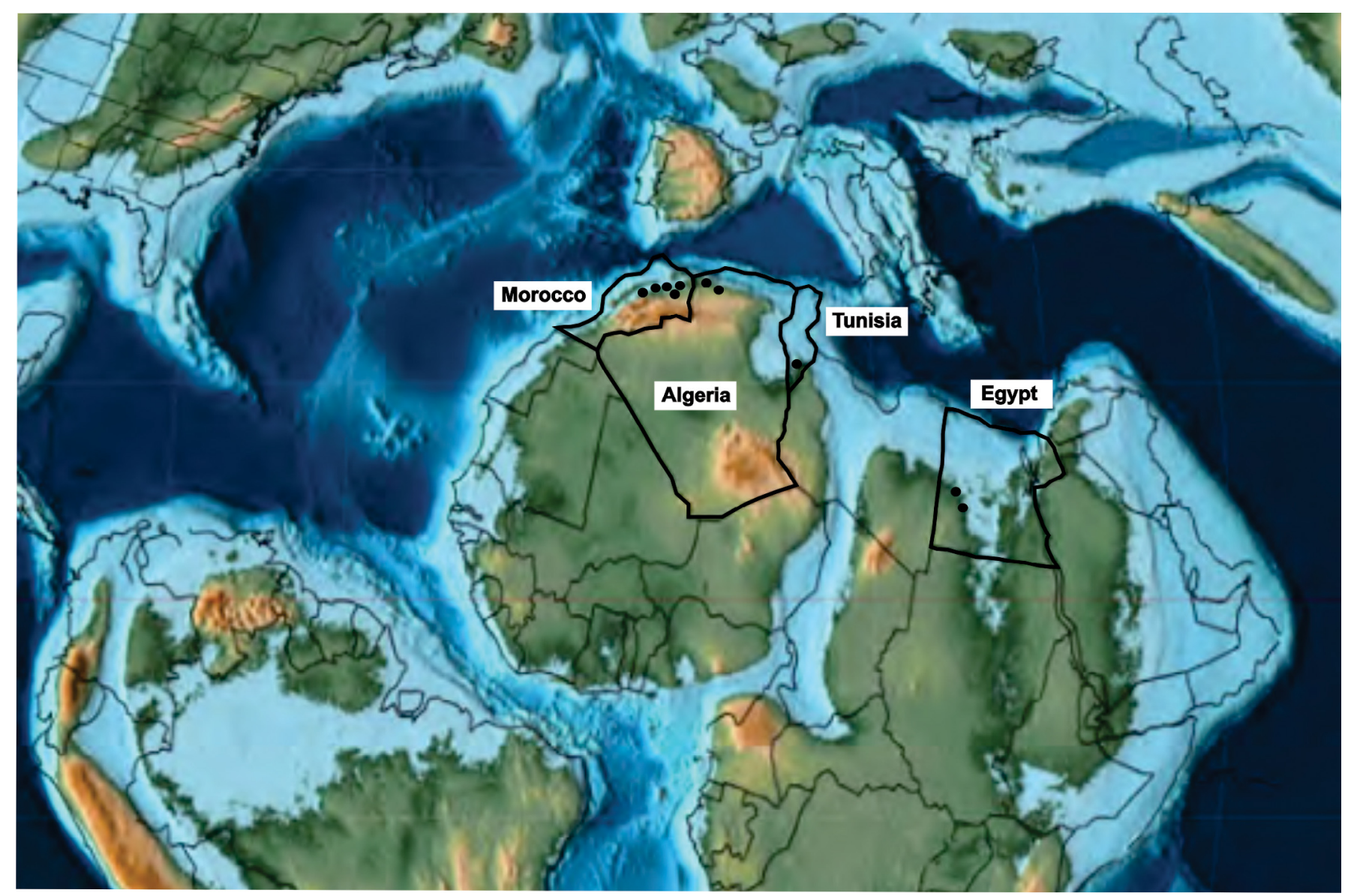

Fig. 2. Gondwanan early Late Cretaceous Spinosaurus species distribution (black points).

Material: BSP 1912 VIII 19-partially complete skeleton with cranial and postcranial elements.

Comments: Spinosaurus aegeptiacus was described by Stromer (1915) after materials found in the rocks of the Bahariya formation, in Central Egypt (Fig. 3). According to Sereno et al. (1998), the layers of this deposit are dated from the Cenomanian. The materials consisted of a small fragment of maxilla, a fragment of jaw, nineteen teeth, two cervical vertebrae, seven dorsal vertebrae, three sacral vertebrae, one caudal vertebrae, some ribs, and elements of the gastralia. The holotype was destroyed during the World War II (Taquet, 1984; Sereno et al., 1999).

\section{Spinosaurus "B"}

Geological unity and age: Bahariya formation, Cenomanian, Egypt.

Material: BSP 1912 VIII 19-vertebrae and hindlimb bones. Comments: Spinosaurus "B" was described by Stromer (1915) and it was found in a locality close to where the aforementioned $S$. aegyptiacus was collected. The material was quite fragmented and Stromer (1934) assigned it as "Spinosaurus B", considering it to be sufficiently different to belong to another species. This material was also destroyed during the World War II.
Early Cenomanian-Algeria/Morocco

Spinosaurus cf. aegyptiacus

Geological unity and age: Kem Kem beds, Algeria, (MNHN SAM 124, MNHN SAM 125-128); Kem Kem beds, early Cenomanian, Morocco (NMC 50791).

Material: NMC 50791 - a mid-cervical vertebra (Russell, 1996); MNHN SAM 124 is from the Gara Samani region, northwestern edge of Tademait (Taquet and Russell, 1998) - a fragment of the rostrum with part of the premaxilla, a fragment of dentary, and vomers; MNHN SAM 125 -a premaxillary fragment; MNHN SAM 126 - a cervical centrum; MNHN SAM 127 - a cervical centrum; MNHN SAM 128 -a dorsal neural arch.

Comments: NMC 50791 was originally described by Russell (1996) as Spinosaurus maroccanus, and other materials were assigned to this species by Taquet and Russell (1998). Later, some authors (e.g., Sereno et al., 1998; Bertin, 2010) confirmed that all specimens assigned to $S$. maroccanus belong to this type species. Taquet and Russell (1998) described other materials that were also from Gara Sami and assigned them to Spinosaurus cf. aegyptiacus (Bertin, 2010).

\section{Early Cenomanian - Morocco}

Spinosaurus cf. aegyptiacus

Geological unity and age: Kem Kem beds, early Cenomanian, Morocco. 
Table 1. Spinosaurus record from North Africa.

\begin{tabular}{|c|c|c|c|c|c|}
\hline Taxa & Locality & Geological unit & Age & Materials & Selected authors \\
\hline \multicolumn{6}{|l|}{ Spinosaurus aegyptiacus } \\
\hline Spinosaurus cf. aegyptiacus & $\begin{array}{l}\text { Jebel Miteur, } \\
\text { Tataouine, Tunisia }\end{array}$ & $\begin{array}{l}\text { Chenini } \\
\text { Formatio }\end{array}$ & Early Albian & Left dentary & $\begin{array}{l}\text { Buffetaut and Ouaja } \\
(2002)\end{array}$ \\
\hline Spinosaurus cf. aegyptiacus & $\begin{array}{l}\text { Taouz municipality, } \\
\text { Morocco }\end{array}$ & Kem Kem beds & $\begin{array}{l}\text { Early } \\
\text { Cenomanian }\end{array}$ & $\begin{array}{l}\text { Premaxillae, maxillae, } \\
\text { external nares, nasals }\end{array}$ & $\begin{array}{l}\text { Dal Sasso et al. } \\
(2005)\end{array}$ \\
\hline Spinosaurus cf. aegyptiacus & $\begin{array}{l}\text { Taouz municipality, } \\
\text { Morocco }\end{array}$ & $\begin{array}{l}\text { "Hammada du } \\
\text { Guir" beds }\end{array}$ & Cenomanina & $\begin{array}{l}\text { An isolated tooth, two } \\
\text { jaw fragments }\end{array}$ & Buffetaut (1989) \\
\hline $\begin{array}{l}\text { Spinosaurus aegyptiacus } \\
\text { Spinosaurus "B" }\end{array}$ & Erfound, Morocco & Kem Kem beds & Cenomanian & Partial skeleton & $\begin{array}{l}\text { Ibrahim et al. (2014) } \\
\text { Stromer (1934) }\end{array}$ \\
\hline Spinosaurus sp. & Tafilalt, Morocco & & & & Buffetaut (1989) \\
\hline $\begin{array}{l}\text { Spinosaurus aegyptiacus } \\
\text { (marrocanus) }\end{array}$ & Gara Samani, Algeria & $\begin{array}{l}\text { Ifezounae } \\
\text { Formation }\end{array}$ & $\begin{array}{l}\text { Early } \\
\text { Cenomanian }\end{array}$ & $\begin{array}{l}\text { Two median cervical } \\
\text { vertebra, dentary } \\
\text { fragments, dorsal neural } \\
\text { arch, }\end{array}$ & Russell (1996) \\
\hline Spinosaurus aegyptiacus & $\begin{array}{l}\text { Béchar municipality, } \\
\text { Western Algeria } \\
\text { UTL.25-MN1 } \\
\text { UTL.25-KDI }\end{array}$ & $\begin{array}{l}\text { "Grès rouges" } \\
\text { Formation, Guir } \\
\text { Basin }\end{array}$ & Cenomanian & Teeth & $\begin{array}{l}\text { Benyoucef et al. } \\
(2015)\end{array}$ \\
\hline Spinosaurus marrocanus & $\begin{array}{l}\text { Gadoufaoua, Aïr } \\
\text { Massif, north Niger; } \\
\text { Gara Samani, Algeria } \\
\text { MNHN SAM }\end{array}$ & $\begin{array}{l}\text { Gadoufaoua, } \\
\text { Gara Samani }\end{array}$ & Albian & $\begin{array}{l}\text { Both premaxillae, } \\
\text { maxillae, vomers, } \\
\text { fragmente of premaxilla, } \\
\text { centra of two cervical } \\
\text { vertebrae, neural arch of } \\
\text { dorsal vertebra }\end{array}$ & Russell (1996) \\
\hline
\end{tabular}

Material: MSNM V4047-a large snout with premaxillae and maxillae and the rostral part of the nasal bones; UCPC2 - caudal part of a pair of nasal bones and a small fragment of a left maxilla.

Comments: MSNM V4047 and UCPC-2 were assigned to Spinosaurus cf. aegyptiacus based on rostral specimens that revealed important information about the paleoecology and body size of this species and positioned it as the largest known species of superpredators from the Cretaceous (Dal Sasso et al., 2005).

\section{Spinosaurus aegyptiacus}

Geological unity and age: Kem Kem beds, early Cenomanian, Morocco.

Material: FSAC-KK 11888 -a partial skeleton of a subadult. Comments: Ibrahim et al. (2014) described the material of a subadult individual assigning it to $S$. aegyptiacus and characterizing it as a neotypic specimen. However, according to Evers et al. (2015), this material can not be considered a neotype due its subadult characteristics.

\section{Spinosaurus cf. aegyptiacus}

Geological unity and age: Kem Kem beds, early Cenomanian, Morocco.

Material: NHM R16420-a premaxilla and a fragment of maxilla; NHM R16420 - a dentary.
Comments: Milner (2003) describes jaws of S. cf. Aegyptiacus. Although brief, the descriptions are significantly informative.

\section{Spinosaurus sp.}

Geological unity and age: Kem Kem formation, early Cenomanian, Morocco.

Material: IMGP 969/1 - a fragment of right maxilla; IMGP 969-2 - a fragment of jaw; IMGP 969-3 - one tooth.

Comments: Buffetaut $(1989,1992)$ assigned these specimens to Spinosaurus sp. The material was collected in the municipality of Taouz, Hammada du Guir, Southeastern Morocco.

\section{Spinosaurus aegyptiacus}

Geological unity and age: Kem Kem beds, early Cenomanian, Morocco.

Material: MHNM.KK374 a.KK375 e.KK377 a.KK378; MSNM V6896 - Five quadrates.

Comments: Hendrickx et al. (2016) recently described five cranial specimens assigned to $S$. aegyptiacus and classified as "Morphotype 1". The material belongs to different individuals and presents distinct ontogenetic stages. These new specimens allowed the authors to infer that these dinosaurs had feeding habits that were not necessarily exclusively piscivorous - a hypothesis that had already been proposed by other authors (e.g., Charig and Milner, 1997; Buffetaut et al., 2004). 


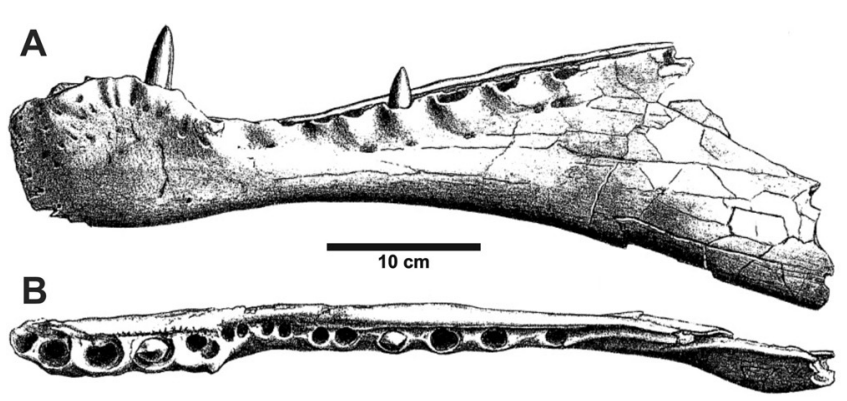

C
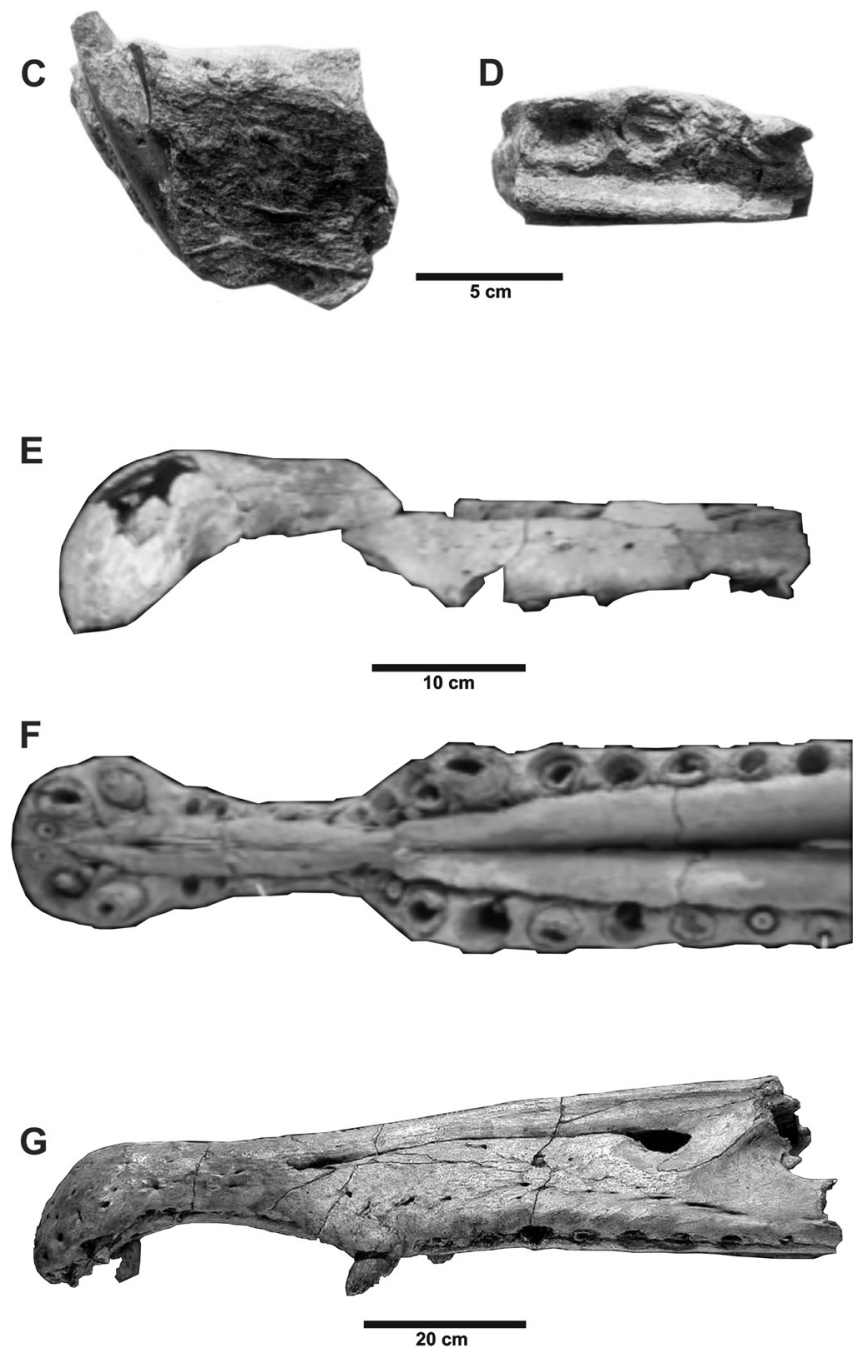

Fig. 3. Most complete Spinosaurus species skulls from early Late Cretaceous formations from Northern Africa. Spinosaurus aegyptiacus (from Stromer, 1915), BSP 1912 -dentary, A in lateral and B in dorsal views. Spinosaurus cf. aegyptiacus (from Buffetaut and Ouaja, 2002), BM231 - rostral part of left dentary, C, in lateral and in D dorsal views. Spinosaurus marrocanus (nomen dubium) (Taquet and Russell, 1998) MNHM SAM 124-left maxilary, E in lateral and F dorsal views. Spinosaurus cf. S. aegyptiacus (from Dal Sasso et al., 2005) MSNM V4047-left maxilary, G in lateral in dorsal view.
Early Cenomanian-Algeria

Spinosaurus aegyptiacus

Geological unity and age: Guir basin, early Cenomanian, Algeria.

Material: UTL25-MN1-12 79-teeth; UTL25-KD1-1 - two teeth.

Comments: The material was recently described by Benyoucef et al. (2015) and it only comprises teeth. These fossil remains were found in the areas of Kénasda and Nenaguir which are part of a larger region known as Continental Intercalaire where rocks of the Kem Kem beds and of the Guir Basin are exposed between Algeria and Morocco. This region has been prolific in fossils, showing a large and diverse terrestrial and marine vertebrate fauna (Cavin et al., 2010).

\section{Results}

\subsection{Distribution of records}

Classically, Spinosaurus is known from incomplete skeletons from Egypt, where the first described material was found. Since the second half of the last century, a significant number of Spinosaurus specimens from Algeria, Morocco, and Tunisia have been formally described (Buffetaut, 1989, 1992; Taquet and Russell, 1998; Benton et al., 2000; Buffetaut and Ouaja, 2002; Milner, 2003; Dal Sasso et al., 2005; Ibrahim et al., 2014; Benyoucef et al., 2015; Hendrickx et al., 2016). Although most material is referable to isolated specimens, some are very well preserved and have been exclusively found in Albian and Cenomanian rocks, suggesting this genus inhabited a large geographic area in North Africa during the middle Cretaceous. Currently, the Cenomanian material is the most representative and abundant fossil record found in Morocco, with a total of six records. Buffetaut (2007) widely discussed the Trans-African similarities between the Cenomanian phases and the spinosaurines from Morocco, Tunisia, and Egypt, pointing out the presence of Spinosaurus along an extensive African Gondwana coast during the mid-Cretaceous. Curiously, despite the fact that the African plate was connected to Europe during some periods and permanently connected to South America at that time, there are no records of Spinosaurus outside Africa, even during the Albian. By the end of the Albian period, a biogeographic barrier appeared with the Atlantic opening, when the depth of this ocean definitely increased (Fig. 4) and its waters became quite cold (Maisey, 2000), preventing the crossing of these large terrestrial predators to South America.

The current records regarding the paleogeographic and stratigraphic distribution of Spinosaurus in northern Gondwana show that these theropods occupied areas represented today by Algeria, Egypt, Morocco, and Tunisia. Spinosaurus aegyptiacus, Spinosaurus cf. aegyptiacus, Spinosaurus "B", and Spinosaurus sp. were discovered in North Africa. Spinosaurus cf. aegyptiacus is recorded from the Albian of both Tunisia and Algeria, while Spinosaurus aegyptiacus is recorded in the early Cenomanian of the latter. In Egypt, the records of Spinosaurus aegyptiacus and Spinosaurus "B" are 
from the early Cenomanian. Finally, the Moroccan record of Spinosaurus aegyptiacus, as well as of three other different specimens of Spinosaurus cf. aegyptiacus and Spinosaurus sp., are all from the early Cenomanian (Fig. 2, Tab. 1).

The genus Spinosaurus is reported from 11 localities from the mid-Cretaceous of North Africa. On the other hand, there are no records of Spinosaurus in other areas of Gondwana or even Laurasia, where other spinosaurids (e.g., Baryonyx, Irritator, Oxalaia, Siamosaurus, Suchomimus) have been recorded (western Europe, southeastern Asia, and northern Brazil) (Bertin, 2010; Candeiro et al., 2017). Therefore, it seems that the paleogeographic distribution of Spinosaurus is the result of a unique faunal interchange that occurred between the Albian and the Cenomanian only in North Africa. The observed distribution of Spinosaurus in this region could be the product of its evolution, dispersion or selective preservation which occurred exclusively in the coastal areas of Africa. Until now, spacial and temporal differences in the composition of the northern Gondwanan species of Spinosaurus are unknown. It is possible that this scenario was induced by this taxonomic "stability" caused by paleoecological trends suitable to the evolution of this taxon. Spinosaurus is the most common theropod reported from North Africa in comparison to other carnivorous dinosaurs. As a consequence, this taxon could have been more numerous than other northern Gondwanan theropods (e.g., Carcharodontosauridae: Carcharodontosaurus saharicus Depéret and Savornin, 1925; Eocarcharia dinops Sereno and Brusatte, 2008; Abelisauridae: Rugops primus Sereno et al., 2004; Spinosauridae/Baryonychinae: Sigilmassasaurus brevicollis Russell, 1996). It is still an enigma why Spinosaurus was not yet found in nearby regions (western Laurasia and eastern Gondwana).

The oldest record of Spinosaurus is from the Ain El Guettar formation, in Tunisia (Buffetaut and Ouaja, 2002), and from the Albian Kem Kem beds in Algeria (Russell, 1996; Taquet and Russell, 1998). The presence of the genus in these formations as well as in the early Cenomanian of the Bahariya formation and Kem Kem beds shows that the derivation of this taxon occurred in northern Gondwana during the first stage of the Late Cretaceous.

The fossil record of Spinosaurus from Cenomanian formations of North Africa is important for many reasons. The 11 records of this genus directly correlates these predators with the abelisaurs and carcharodontosaurs from areas of the same age in Algeria, Egypt, and Morocco (Novas et al., 2013; Candeiro, 2015) - today these areas are in the northern eastwest edge of Africa. Hence, this also correlates the Spinosaurus record with the chronostratigraphic time scale of the Gondwanan pattern of northern Gondwana. These correlations indicate that this group became top predators in a large area of occurrence where other megacarnivorous were also present.

This study shows that the geographic distribution of the genus Spinosaurus was generalized during the mid-Cretaceous. The fossil record of this spinosaurinae suggests the existence of faunal connections in the beginning of the Late Cretaceous that occurred only among the areas of North Africa. These theropods were terrestrial animals that lived nearby coastal environments (Cavin et al., 2010; Candeiro et al., 2011) and, thus, it depended of land bridges as migration routes. By the end of the Albian period, these land bridges that

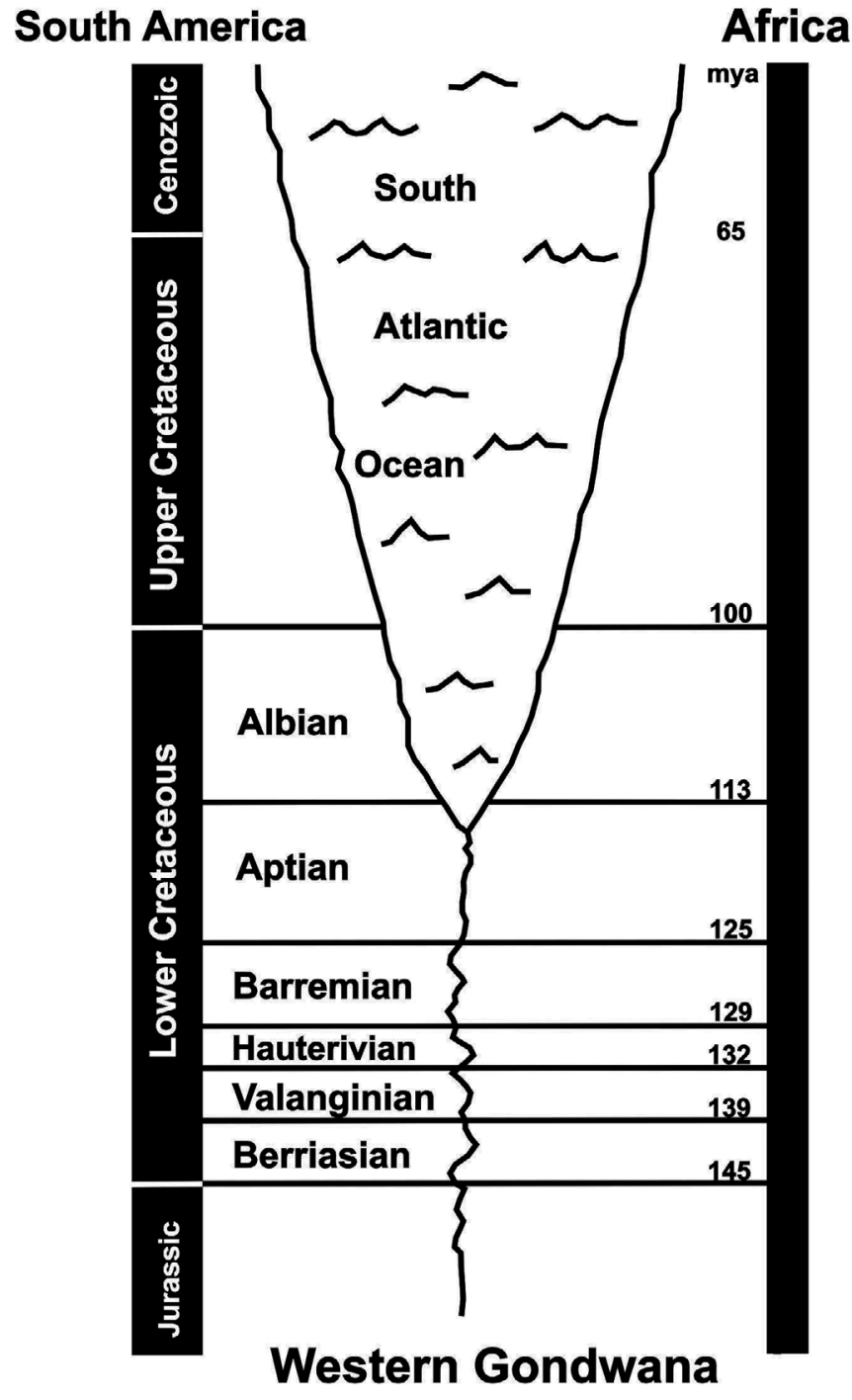

Fig. 4. Block diagram of the break up between the Africa and South America plates during the Cretaceous (modified from Maisey 2000).

connected the African plate with Europe and South America no longer existed. Today, the fossil record of Spinosaurus suggests that this taxon originated in certain areas of North Africa during the Albian and later dispersed to other northern areas of this continent. Their records from the mid-Cretaceous of northern Gondwana are unique because the paleogeographic reconstructions during the Albian-Cenomanian of Africa actually reflects a restricted distribution in middle latitudes from east to west. During the Late Albian and the Cenomanian, the northern part of Gondwana suffered with marine ingressions (Maisey, 2000). As a consequence, no faunal interchange among terrestrial dinosaurs occurred between Africa and Northern Brazil, since the marine waters possibly became a physical barrier to their dispersal.

\subsection{Macrohabitat niche}

In the literature, the mid-Cretaceous occurrence and preference of Spinosaurus for coastal regions and brackish waters of northern Gondwana is documented (Russell, 1996; 


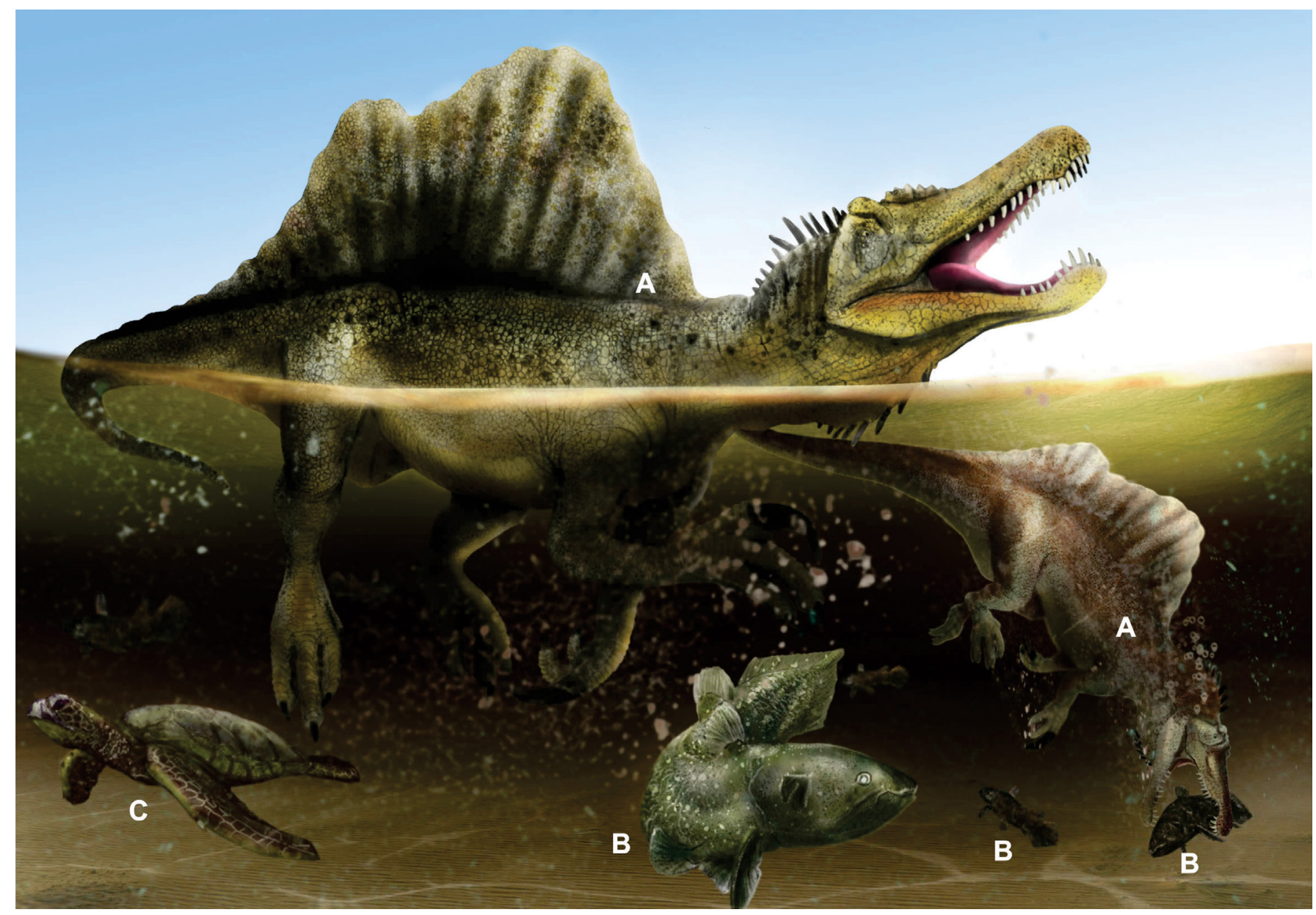

Fig. 5. Semi-aquatic paleoenvironmental reconstruction of Spinosaurus dinosaur during early Late Cretaceous: (A) Spinosaurus; (B) Mawsonia coelacanth fishes; (C) Araripemys turtle (drawing Luciano Vidal).

Russell and Paesler, 2003; Smith et al., 2006). More precisely, the primary habitats used by Spinosaurus were flooded areas nearby deltas (Bertin, 2010). The preference of the northern Gondwanan Spinosaurus for mangroves and other coastal areas where brackish waters occur is probably related to the local environmental characteristics that were common to the marginal areas of Africa during the mid-Cretaceous. Naturally, these regions also had fresh water courses (see Buffetaut, 1989; Buffetaut and Ouaja, 2002; Bertin, 2010) since this large spinosaurinae was apparently absent in inland areas of the continent where other freshwater sources were present. Spinosaurus is also known in coastal lagoons and estuarine environments all over western Africa (Buffetaut and Ouaja, 2002; Bertin, 2010) (Fig. 5). Therefore, our regional data fully confirm the previously known information that the niches occupied by this genus were related to coastal environments.

This analysis considers a small possibility of competitive interactions between both forms (maybe different in body size) of Spinosaurus (S. aegptiacus [Stromer, 1915]), Spinosaurus cf. aegyptiacus (Dal Sasso et al., 2005) and Spinosaurus sp. (Buffetaut, 1989) that inhabited the same areas of Morocco during the Cenomanian. We suggest that the body size difference between these taxa allowed them to coexist in the same habitat and probably produced dietary differences that minimized competition, as previously shown in other reptile taxa (see Pianka, 1973, 1986; Oliveira et al., 2013). Corroborating with this, these results show that it is likely that both species differed in habitat use. However, we cannot exclude the possibility that niche differences were driven by competition (Connell, 1980; Farlow and Pianka, 2002; Oliveira et al., 2013).

\section{Remarks}

The middle Cretaceous strata of North Africa preserved an important record of the theropod Spinosaurus. Although their fossil remains are usually fragmented, most specimens show diagnostic characters of the genus Spinosaurus that are especially present in their conical and non-serrated teeth. The fossil record of this genus in North Africa shows a restricted geographic distribution between the Albian and the Cenomanian periods. Yet, when we consider their temporal distribution, it suggests that Spinosaurus had a significant geological history of nearly 20 million years, a lifespan unknown for other African megapredators species (e.g., Carcharodontosaurus 18.5 mya [Candeiro et al., 2018]). The geological evidences indicate that Africa was an island during the main period of 
occurrence of this genus. The faunal composition of the spinosaurinae that inhabited the eastern coast of Africa is broadly comparable with the Cenomanian fossil records from western Africa, supporting the relative homogeneous composition of the taxon in these areas during this period. Additional studies and future field prospections in other localities could eventually reveal a wider distribution of this genus in other regions of Africa (e.g., Niger, Sudan) or even in western Europe and northern South America.

\section{Institutional abbreviations}

MSNM Museo di Storia Naturale di Milano; Milan/Italy UCPC University of Chicago Paleontological Collection UTL University of Tlemcen/Laboratory, Algeria

FSAC Faculté des Sciences Aïn Chock, Casablanca, Morroco

IMGP Georg-August-Universität in Göttingen, Germany

Acknowledgments. Gareth Dyke (England) is thanked for his constructive early reviews and Bruno Ferré (France) by resumé version. R. Candeiro was partially supported by the Conselho Nacional de Ciência e Tecnologia by Produtividade e Pesquisa fellowship. L. Gil is also supported by a Coordenação de Aperfeiçoamento de Pessoal de Nível Superior/CAPES master fellow. We thank the two anonymous reviewers for their helpful comments.

\section{References}

Arai M. 2015. Aptian/Albian (Early Cretaceous) paleogeography of the South Atlantic: a paleontological perspective. Brazilian Journal of Geology 44: 339-350.

Benson RBJ. 2010. A description of Megalosaurus bucklandii (Dinosauria: Theropoda) from the Bathonian of the UK and the relationships of Middle Jurassic theropods. Zoological Journal of the Linnean Society 158: 882-935.

Benton MJ, Bouaziz S, Buffetaut E, Martill D, Ouaja M, Soussi M, et al. 2000. Dinosaurs and other fossil vertebrates from fluvial deposits in the Lower Cretaceous of southern Tunisia. Palaeogeography, Palaeoclimatology, Palaeoecology 157(3-4): 227-246.

Benyoucef M, Läng E, Cavin L, Mebarki K, Adaci M, Bensalah M. 2015. Overabundance of piscivorous dinosaurs (Theropoda: Spinosauridae) in the mid-Cretaceous of North Africa: The Algerian dilemma. Cretaceous Research 55: 44-55.

Bertin T. 2010. A catalogue of material and review of the spinosauridae. PalArch's Journal of Vertebrate Palaeontology 7 (4): 1-39.

Bouaziz S, Buffetaut E, Ghanmi M, Jaeger JJ, Martin M, Mazin JM, et al. 1988. Nouvelles découvertes de vertébrés fossiles dans l'Albien du Sud tunisien. Bulletin de la Société géologique de France 8: 335-339.

Buffetaut E. 1989. New remains of the enigmatic dinosaur Spinosaurus from the Cretaceous of Morocco and the affinities between Spinosaurus and Baryonyx. Neues Jahrbuch für Geologie und Paläontologie, Monatshefte 2: 79-87.

Buffetaut E. 1992. Remarks on the Cretaceous theropod dinosaurs Spinosaurus and Baryonyx. Neues Jahrbuch für Geologie und Paläontologie, Monatshefte 2: 88-96.
Buffetaut E. 2007. The spinosaurid dinosaur Baryonyx (Saurischia, Theropoda) in the Early Cretaceous of Portugal. Geological Magazine 144: 1021-1025.

Buffetaut E, Ouaja M. 2002. A new specimen of Spinosaurus (Dinosauria, Theropoda) from Lower Cretaceous of Tunisia, with remarks on the evolutionary history of the Spinosauridae. Bulletin de la Société géologique de France 173(5): 415-421.

Buffetaut E, Martill D, Escuillié F. 2004. Pterosaurs as part of a spinosaur diet. Nature 430(6995): 33.

Candeiro CRA. 2015. Middle Cretaceous dinosaur assemblages from northern Brazil and northern Africa and their implications for northern Gondwanan composition. Journal of South American Earth Sciences 61: 147-153.

Candeiro CRA, Fanti F, Therrien F, Lamanna MC. 2011. Continental fossil vertebrates from the mid-Cretaceous (Albian-Cenomanian) Alcântara Formation, Brazil, and their relationship with contemporaneous faunas from North Africa. Journal of African Earth Sciences 60: 79-92.

Candeiro CRA, Brusatte SL, Souza-Junior AL. 2017. Spinosaurid dinosaurs from the Early Cretaceous of North Africa and Europe: fossil record, biogeography and extinction. Anuário do Instituto de Geociências-UFRJ 40: 294-302.

Candeiro CRA, Brusatte SL, Vidal LS, Pereira PVLGC. 2018. Paleobiogeographic evolution and distribution of Carcharodontosauridae during the middle Cretaceous of North Africa. Papéis Avulsos de Zoologia (São Paulo), 58: e201858Fascículo.

Canudo JI, Barco JL, Pereda-Suberbiola X, Ruiz-Omeñaca JI, Salgado L, Torcida Fernández-Baldor F, et al. 2009. What Iberian dinosaurs reveal about the bridge said to exist between Gondwana and Laurasia in the Early Cretaceous. Bulletin de la Société géologique de France 180: 5-11.

Cavin L, Tong H, Boudad L, Meister C, Piuz A, Tabouelle J, et al. 2010. Vertebrate assemblages from the early Late Cretaceous of southeastern Morocco: an overview. Journal of African Earth Sciences 57(5): 391-412.

Charig AJ, Milner AC. 1986. Baryonyx, a remarkable new theropod dinosaur. Nature 324: 359-361.

Charig AJ, Milner AC. 1997. Baryonyx walkeri, a fish-eating dinosaur from the Wealden of Surrey. Bulletin of the Natural History Museum, Geology Series 53: 11-70.

Charton R, Bertotti G, Arantegui A, Bulot L. 2018. The Sidi Ifni transect across the rifted margin of Morocco (Central Atlantic): Vertical movements constrained by low-temperature thermochronology. Journal of African Earth Sciences 141: 22-32.

Connell JH. 1980. Diversity and the coevolution of competitors, or the ghosts of competition past. Oikos 35: 131-138.

Dal Sasso C, Maganuco S, Buffetaut E, Mendez MA. 2005. New information on the skull of the enigmatic Spinosaurus, with remarks on its sizes and affinities. Journal of Vertebrate Paleontology 25(4): 888-896.

Depéret C, Savornin J. 1925. Sur la découverte d'une faune de vertèbres albiens à Timimoun (Sahara occidental). Comptes Rendus de l'Académie des Sciences de Paris 181: 1108-1111.

Evers SW, Rauhut OWM, Milner AC, McFeeters B, Allain R. 2015. A reappraisal of the morphology and systematic position of the theropod dinosaur Sigilmassaurus from the "middle" Cretaceous of Morocco. PeerJ 3: e1323.

Farlow J, Pianka ER. 2002. Body Size overlap, habitat partitioning and living space requirements of terrestrial vertebrate predators: implications for the paleoecology of large theropod dinosaurs. Historical Biology 16: 21-40.

Hay W, Deconto R, Wold C, Wilson K, Voigt S, Schulz M, et al. 1999. Alternative global Cretaceous paleogeography. In: Barrera E, 
Johnson C, eds. Evolution of the Cretaceous ocean/climate system. Geological Society of America Special Paper Boulder Co. 332: $1-47$.

Hendrickx C, Mateus O, Buffetaut E. 2016. Morphofunctional analysis of the quadrate of Spinosauridae (Dinosauria: Theropoda) and the presence of Spinosaurus and a second Spinosaurine taxon in the Cenomanian of North Africa. PLoS ONE 11: e0144695.

Hone DWE, Holtz TR, Jr. 2017. A century of spinosaurs - a review and revision of the Spinosauridae with comments on their ecology. Acta Geologica Sinica (English edition) 91(3): 1120-1132.

Ibrahim N, Sereno PC, Dal Sasso C, Maganuco S, Fabbri M, Martill $\mathrm{DM}$, et al. 2014. Semiaquatic adaptations in a giant predatory dinosaur. Science 345(6204): 1613-1616.

Maisey JG. 2000. Continental break up and the distribution of fishes in western Gondwana during the Early Cretaceous. Cretaceous Research 21: 281-314.

Martill DM, Hutt S. 1996. Possible baryonychid dinosaur teeth from the Wessex Formation (Lower Cretaceous, Barremian) of the Isle of Wight, England. Proceedings of the Geologists Association 107: $81-84$.

Melo AC, de Castro DL, Bezerra FHR, Bertotti G. 2016. Rift fault geometry and evolution in the Cretaceous Potiguar Basin (NE Brazil) based on fault growth models. Journal of South American Earth Sciences 71: 96-107.

Milner AC. 2003. Fish-eating theropods: a short review of the systematics, biology and palaeobiogeography of spinosaurs. II Jornadas Internacionales sobre paleontología de Dinosaurios y su Entorno: 129-138.

Novas FE, Agnolin F, Ezcurra MD, Porfiri J, Canale JI. 2013. Evolution of the carnivorous dinosaurs during the Cretaceous: The evidence from Patagonia. Cretaceous Research 45: 174-215.

Oliveira MCLM, Santos MB, Loebman D, Hartman A, Tozetti AM. 2013. Diversity and associations between coastal habitats and anurans in southernmost Brazil. Anais da Academia Brasileira de Ciências 85: 113-121.

Pianka ER. 1973. The structure of lizard communities. Annual Review of Ecology and Systematics 4: 53-74.

Pianka ER. 1986. Ecology and natural history of desert lizards: Analyses of the ecological niche and community structure. Princeton: Princeton University Press.

Pitman WC, Cande S, LaBrecque J, Pindell J. 1993. Fragmentation of Gondwana: The separation of Africa from South America, pp. 1534. In: Goldblatt P, ed. Biological relationships between Africa and South America. New Haven: Yale University Press, 360 p.

Pletsch T, Erbacher J, Holbourn AEL, Kuhnt W, Moullade M, ObohIkuenobede E, et al. 2001. Cretaceous separation of Africa and South America the view from the West margin (ODP Leg 159). Journal of South American Earth Sciences 14: 147-174.

Rayfield EJ, Milner AC, Xuan VB, Young PG. 2007. Functional morphology of spinosaur 'crocodile-mimic' dinosaurs. Journal of Vertebrate Paleontology 27(4): 892-901.
Russell DA. 1996. Isolated dinosaur bones from the Middle Cretaceous of the Tafilalt, Morocco. Bulletin du Muséum National d'Histoire Naturelle, Paris, $4^{e}$ série, section C 18(2-3): 349-402.

Russell DA, Paesler MA. 2003. Environments of Mid-Cretaceous Saharan dinosaurs. Cretaceous Research 24: 569-588.

Sereno PC, Brusatte SL. 2008. Basal abelisaurid and carcharodontosaurid theropods from the Lower Cretaceous Elrhaz Formation of Niger. Acta Palaeontologica Polonica 53: 15-46.

Sereno PC, Beck AL, Dutheuil DB, Gado B, Larsson HC, Lyon GH, et al. 1998. A long-snouted predatory dinosaur from Africa and the evolution of spinosaurids. Science 282: 1298-1302.

Sereno, PC, Beck AL, Dutheil DB, Larsson HCE, Lyon GH, Moussa B, et al. 1999. Cretaceous sauropods from the Sahara and the uneven rate of skeletal evolution among dinosaurs. Science 286: 1342-1347.

Sereno PC, Wilson JA, Conrad JL. 2004. New dinosaurs link southern landmasses in the Mid-Cretaceous. Proceedings of the Royal Society of London B 271: 1325-1330.

Smith JB, Lamanna MC, Mayr H, Lacovara KJ. 2006. New information regarding the holotype of Spinosaurus aegyptiacus Stromer, 1915. Journal of Paleontology 80(2): 400-406.

Stromer E. 1915. Ergebnisse der Forschungsreisen Prof. E. Stromers in den Wüsten Ägyptens II. Wirbeltier-Reste der Baharije-Stufe (unterstes Cenoman). Das original des Theropoden Spinosaurus aegyptiacus nov. gen. Spe. Abhandlungen der Königlich Bayerischen Akademie der Wissenschaften, Mathematisch-physikalische Klasse 28(3): 1-32.

Stromer E. 1934. Ergebnisse der Forschungsreisen Prof. E. Stromers in den Wüsten Ägyptens. II. Wirbeltier-Reste der Baharije-Stufe (unterstes Cenoman). 13. Dinosauria. Abhandlungen der Bayerischen Akademie der Wissenschaften Mathematisch-naturwissenschaftliche Abteilung, Neue Folge 22: 1-79.

Strozyk F, Back S, Kukla PA. 2017. Comparison of the rift and post-rift architecture of conjugated salt and salt-free basins offshore Brazil and Angola/Namibia, South Atlantic. Tectonophyiscs 716: 204-224.

Taquet P. 1984. Une curieuse spécialisation du crâne de certains dinosaures carnivores du Crétacé : le museau long et étroit des spinosauridés. Compte Rendus de l'Académie des Sciences, Sciences de la Terre et des Planètes 299: 217-222.

Taquet P, Russell DA. 1998. New data on spinosaurid dinosaurs from the Early Cretaceous of the Sahara. Comptes Rendus de l'Académie des Sciences-Series IIA-Earth and Planetary Sciences 327(5): 347-353.

Torices A, Barroso-Barcenilla F, Cambra-Moo O, Pérez-García A, Segura M. 2012. Palaeontological and palaeobiogeographical implications of the new Cenomanian vertebrate site of Algora, Guadalajara, Spain. Cretaceous Research 37: 231-239.

Zarconea G, Pettib FM, Cillaric A, Stefanoa P, Guzzettad D, Nicosiac U. 2010. A possible bridge between Adria and Africa: New palaeobiogeographic and stratigraphic constraints on the Mesozoic palaeogeography of the Central Mediterranean area. Earth ScienceReviews 103(3-4): 154-162.

Cite this article as: Candeiro CRA, Gil LM, de Castro PEP. 2018. Large-sized theropod Spinosaurus: an important component of the carnivorous dinosaur fauna in southern continents during the Cretaceous, BSGF - Earth Sciences Bulletin 189: 15. 